A N N A LE S

UNIVERSITATIS MARIAE CURIE-SKŁODOWSKA LUBLIN - POLONIA

VOL. LXXI

SECTIO F

2016

Serbska Akademia Nauk i Sztuk

Instytut Bałkanologii

\title{
MILOŠ LUKOVIĆ
}

I. Komatina, Crkva i država u srpskim zemljama od XI do XIII veka, Istorijski institut, Beograd 2016, ss. 1-446

Tytuł recenzowanej książki po polsku brzmi: Kościót i państwo na ziemiach serbskich od XI do XIII wieku. Autorka, Ivana Komatina, należy do kręgu młodszych pracowników naukowych Instytutu Historii w Belgradzie (zajmuje się on badaniem serbskiej historii narodowej do nastania państwa jugosłowiańskiego w 1918 r.). Na początku książki (Stowo autora, s. 7) badaczka podkreśla, że praca jest właściwie jej rozprawą habilitacyjną, która została obroniona na Uniwersytecie Belgradzkim w 2013 r.

Tak jak autorka sygnalizuje we Wstępie (s. 9-12), w pracy omawiana jest wielowarstwowa relacja i wzajemne uwarunkowanie między Kościołem a państwem w okresie od XI do XIII w. na terytorium ówczesnych serbskich ziem (Serbia, Dukla, Trawunia, Hum/Zahumle i Bośnia), które do XIII w. de facto były zależne od Bizancjum lub pozostawały pod wpływem Republiki Dubrownickiej, Republiki Weneckiej, Węgier i Bułgarii. Termin „Kościół” odnosi się zarówno do Kościoła prawosławnego, rzymskokatolickiego, jak i do kanonicznie nieuznawanych ruchów i wspólnot heretyckich. Dolną granicą chronologiczną badań jest XI w., w którym rozpoczęła się reorganizacja władzy Bizancjum na Bałkanach oraz bardziej intensywna walka Serbów o założenie niezależnych państw. Jednocześnie był to czas wzmocnionego działania wspólnot heretyckich na Bałkanach oraz pierwszych otwartych konfliktów między Archidiecezją Dubrownicką i Barską (Bar jest miejscowością leżącą na Wybrzeżu Adriatyckim, obecnie na terenie Czarnogóry). W monografii zostały przedstawione również wydarzenia na Bałkanach z wcześniejszych wieków, które bezpośrednio wpłynęły na sytuację w XI stuleciu. Z kolei XIII w. był okresem pełnej niezależności serbskiego państwa, w ramach którego w całości zostały zintegrowane takie obszary, jak Dukla, Tra- 
wunia i Hum/Zahumle, a władcy serbscy prowadzili dalszą ekspansję w kierunku południowo-wschodnim. Od 1219 r. w państwie serbskim funkcjonował też Autokefaliczny Kościół Prawosławny - Serbskie Arcybiskupstwo (Srpska arhiepiskopija), niezależne od Patriarchatu Konstantynopolitańskiego (Carigradska patrijaršija). Ponadto w granicach monarchii serbskiej (przeważnie w rejonach nadmorskich) zamieszkiwali także katolicy. Jurysdykcja nad nimi była przedmiotem długotrwałych sporów: najpierw między Archidiecezją Dubrownicką i Barską, a następnie między Archidiecezją Barską a Kotorską (Kotor znajduje się w Zatoce Kotorskiej, obecnie na terenie Czarnogóry).

W XIII w. w Bośni, która wówczas niezależnie od Serbii dążyła do rozwoju własnej państwowości, władzę nad Kościołem katolickim przejęli heretyccy bogomili, a począwszy od 1291 r., jedynymi prawomocnymi przedstawicielami tego Kościoła na obszarze Bośni stali się franciszkanie. Kościelne i wyznaniowe relacje ustalone pod koniec XIII w. w państwie serbskim i bośniackim utrzymały się do drugiej połowy XV w., do ekspansji Imperium Osmańskiego.

Rozważania autorki zostały poprzedzone Wykazem skrótów (s. 13-29) używanych w tekście.

We Wstępie (s. 31-50) mowa jest o: organizacji politycznej i kościelnej Imperium Rzymskiego na Bałkanach od IV do VII w.; osiedlaniu Słowian, ich chrystianizacji i następujących w związku z tym zmianach w organizacji kościelnej; ukształtowaniu nowych struktur państwowych na Bałkanach; umocnieniu i rozszerzeniu Patriarchatu Konstantynopolitańskiego na Bałkanach w VIII i IX w.; reakcji Kościoła rzymskokatolickiego.

Po Wstępie następują trzy obszerne rozdziały. W pierwszym, zatytułowanym Między Rzymem a Konstantynopolem (XI i pierwsza połowa XII wieku) (s. 51-156), przedstawiono szczegółowo takie zagadnienia, jak: odnowa ośrodków kościelnych w IX i X w. w Splicie, Dubrowniku i Durrës (obecnie na terenie Albanii) oraz utworzenie Kościoła bułgarskiego; rozwój Arcybiskupstwa Ochrydzkiego w granicach Bizancjum; nadmorskie centra kościelne w granicach Bizancjum; dążenia Serbów do niepodległości; Bośnia między Wschodem a Zachodem.

$\mathrm{W}$ drugim rozdziale - Zatargi religijne i (nie)moc państwa (druga połowa XII i początek XIII wieku) (s. 157-246) - omówiono następujące zagadnienia: prawosławie i herezja w serbskim państwie Stefana Nemanji (założyciela dynastii Nemanjiciów); katolicyzm w miastach na Wybrzeżu Adriatyckim między Dubrownikiem a Barem; pojawienie się herezji (bogomilstwo) w Bośni.

$\mathrm{W}$ trzecim rozdziale - Modus vivendi. Od konfliktu do wspótistnienia (XIII wiek) (s. 247-362) - mowa jest o: założeniu i organizacji Serbskiego Arcybiskupstwa Prawosławnego; rozwiązaniu sporu między Archidiecezją Dubrownicką a Barską; utworzeniu profilu Kościoła bośniackiego opartego na bogomilstwie (Bosanska crkva). 
W ostatniej części książki (Epilog, s. 363-388) autorka wyjaśnia stabilizację sytuacji w drugiej połowie XIII w. w Arcybiskupstwie Serbskim, Kościele rzymskokatolickim na terenie Serbii, w Kościele bośniackim i innych organizacjach kościelnych na terenie Bośni.

Po Epilogu następują Załączniki (s. 389-394). Jest to właściwie wykaz informacji: 1) Arcybiskupi Arcybiskupstwa Bułgarskiego/Ochrydzkiego, 2) Arcybiskupi Arcybiskupstwa Serbskiego, 3) Arcybiskupi Archidiecezji Dubrownickiej, 4) Biskupi i Arcybiskupi Archidiecezji Barskiej, 5) Biskupi Diecezji Bośniackiej, 6) Przegląd bulli papieskich: a) dotyczący Archidiecezji Dubrownickiej, b) dotyczący Archidiecezji Barskiej.

Książka zawiera też streszczenie (Summary) w języku angielskim (s. 395408) oraz obszerną bibliografię (źródła, literatura; s. 409-426). Autorka podkreśla względne bogactwo istotnych źródeł dotyczących omawianej materii oraz okresu, którym się zajmuje.

W monografii znajduje się sześć wyjątkowo czytelnych kolorowych map (ich wykaz umieszczono na s. 427). Są to: 1) Rzymska organizacja administracyjna i kościelna na Bałkanach: V-VI w., 2) Polityczna i kościelna organizacja na Bałkanach: VII-IX w., 3) Kościelna organizacja na Bałkanach: X w., 4) Kościelna organizacja na ziemiach serbskich i w sąsiedztwie: XI i XII w., 5) Kościelna organizacja na ziemiach serbskich i w sąsiedztwie: XII w., 6) Kościelna organizacja na ziemiach serbskich: XIII w.

Obszerny Rejestr (s. 429-446) na końcu publikacji obejmuje imiona własne, nazwy miast, ośrodków kościelnych, monastyrów i inne toponimy.

Można stwierdzić, że książka Ivany Komatiny dokładnie omawia relacje Kościoła i państwa na ziemiach serbskich w okresie od XI do XIII w., zarysowując różne poziomy tych relacji: jeden poziom przedstawia wpływ państwa na ukształtowanie siedzib kościelnych i ich jurysdykcji (Archidiecezja Barska, Archidiecezja Dubrownicka, Archidiecezja Kotorska, Arcybiskupstwo Serbskie); drugi poziom to wpływ państwa na instytucjonalizację ruchu heretyckiego, takiego jak bogomilstwo w Bośni; trzeci poziom to oddziaływanie państwa na sprawy religijne oraz działania kulturalne w ramach Kościoła. Z drugiej strony Kościół często wpływał na orientację polityki zagranicznej władców, przy czym Kościoły prawosławny i rzymskokatolicki działały w ramach jednego państwa, co wymagało naświetlenia przez autorkę ich wzajemnych relacji, a także stosunku obu Kościołów do ośrodków i wspólnot heretyckich. Książka właściwie ukazuje szerszą panoramę organizacji kościelnej i politycznej na Bałkanach w okresie od XI do XIII w. i oferuje kompleksowe wyjaśnienie wszystkich procesów przeplatających się w obrębie kościelnych i państwowych struktur na tych terenach. Bez tego nie można zrozumieć wydarzeń, które nastąpiły na Bałkanach w XIV w. W drugiej połowie tego stulecia pojawił się bowiem nowy czynnik zróżnicowania religijnego na Bałkanach - islam, który dał podstawy koncepcji Imperium Osmańskiego. 